\title{
Research on Moral Hazard and Control Methods of Civil Servants in New Era
}

\section{Xuefeng Lv}

Hubei Administration College, The research base of the party school of the research center of the socialist theory system of socialism with Chinese characteristics in Hubei province, Wuhan, 430000, China

Keywords: Moral hazard, Control methods, Civil servants

\begin{abstract}
China has entered a new era of socialism with various risks. Among them, the moral risk of Chinese civil servants is particularly prominent. It has seriously affected the image of our government, and even shaken the people's trust in our party and government. Therefore, in the way of building a well-off society in an all-round, we should control the moral hazard of civil servants from the aspects of perfecting education process, strengthening mechanism construction and establishing supervision system.
\end{abstract}

\section{Introduction}

Moral hazard is involved in economic activities of the parties to the interests of the individual to make the harmful behavior of others; or moral risk is to meet the desires and pay any effort behavior. While economists in different areas is interpreted as the moral risk is as greedy speculators. If it goes beyond the scope of economics, so the moral hazard refers to the moral behavior, moral behavior, no purpose refers to the moral behavior itself is not the fundamental motivation also refers to a series of social problems is a kind of social behavior may lead to behavior, this uncertainty is mainly the potential of the possible outcomes and risk based on. Moral hazard refers to achieve their own interests and objectives of the authority to meet their own, which also violated the principle of morality. In other words, not all with dishonest behavior imposed on many working people is civil servants moral risk behavior. With the development of social reform period, facing the complex changes in the domestic environment, China's civil servants to approach the problem is not the same. The social transformation is a long-term potential process. In the present stage of our country in the primary stage of socialism, the socialist road in exploring in advance, and entering the transition period. Moral hazard is caused by negative behavior. The specific performance of moral awareness is weak, everything is not responsible. Because of the economic globalization of world diversification, the western developed countries which polluted the traditional thought of some bad ideas. This leads to moral measures lag and not with the actual measures taken. The civil servants began to study the system of virtue, what place has defects, even though the moral hazard is perfectly logical and reasonable, lead to moral risks emerge in an endless stream of new.

\section{Moral Hazard of Civil Servants in New Era}

\subsection{Economical Corruption}

In the current market economy environment, the commodity exchange presents the characteristics of the heavy, but also the part of the world outlook, outlook on life and values have changed greatly, some bad thought to breed, few civil servants in the work by hand rights corruption, repeated corruption, not only seriously corrupt party also, the social atmosphere pollution, has brought serious challenges to the party's principles. Few civil servants have serious government standard consciousness, make full use of the power in the hands of the realization of personal value, vigorously bartering, not only ruined the party, but also led to the spread of corruption, bring serious influence to the people image, serious damage between the party and the people, the party and the country's reputation brought the larger the damage. This also makes it urgent to strengthen the construction of 
civil servants' professional ethics. Real estate is a good example. Scholars who have been engaged in social problems have made statistical investigations. The survey shows that the high price of housing is the reason of the government, among which the collusion between government and businessmen is the most prominent. Embezzlement and embezzlement emerge one after another. For the occupation moral construction of civil servants, although moral legislation is very important and very urgent, but more important is to want from the moral legislation external compulsion to moral self-discipline, strengthen the functions of education, civil responsibility consciousness and moral education. Civil servants take corruption and bribery as the main administrative purpose, the phenomenon is endless, showing new features. Money refers to the civil power to acquire the money and property transactions. The market economy is the principle of fair competition, bartering broke the fair competitive situation, to a certain extent, a threat to the safety of people's property.

\subsection{Life Erosion}

Civil servants as the representative of the interests of the people and the will of the administrative system in China, as servants of the people, but in fact, due to all kinds of bad ideas, few civil servants' hedonism phenomenon is very prominent, and from the masses, regardless of work efficiency, irresponsible, always put their own interests in the first place, make full use of his power for personal gain. Our emotional understanding of civil servants Accountability Act, cannot be ignored is that it covered an important fact, decision of administrative behavior is closely related with moral hazard is usually irreversible, and the more important decisions can be replicated. The civil service corruption caused by the need for corruption to meet the needs of the target, the pursuit is the basis of behavior. People need to meet with the level and extent of progressive. Therefore, civil servants are often due to the need to constantly improve and resulting in serious corruption. Need only show enthusiasm as a psychological tendency and behavior, when the tendency to by means of a certain specific, the establishment will reach the behavior and motivation. Motivation is the direct cause of corruption, it shows that the civil servants through non-legitimate, violates the social norms of behavior means to meet the individual needs has identity, and will promote the behavior to reach the target. Because each time, location, characters and events and other factors are changing, because of this, we should be on the civil service accountability and accountability, in the specific operation is full of elasticity. Irreversible behavior leads to unpredictable, moral hazard will enlarge civil servant's accountability process. The trading is a way of bribery, bribery of officials to meet. It is further bartering. By lust, so officials condone his abuse of power.

\subsection{Political Degeneration}

Right trading is the development of bartering and trading the right color deeper, around the power of bureaucratic group. China is a socialist country, trading rights is not conducive to China's political democratization, is not conducive to the implementation of multi-party cooperation system policy of our country, is a source of political risk in china. The crime of dereliction of duty refers to the national staff are not serious about their work, do not conform to the rules or do not perform their duties, dereliction of duty and illegal acts, serious damage to the interests of the people of the country lost. Monopoly public service provides, as a relatively rational people, civil servants naturally do not have enough pressure or motivation to improve their work behavior, improve work efficiency, optimize the quality of public service, to mobilize more of their own work enthusiasm, initiative and creativity. The biggest difference between the government and other economic organizations lies in the fact that the government finally pursues fairness and justice, and is striving to promote the welfare of the whole society. If a country's civil servants moral hazard phenomenon cannot be effectively controlled, it will undoubtedly accelerate the breeding and spreading of such corrupt thought and behavior. As the authority of national government, negative demonstration effect of this kind of behavior will give various industries and sectors of society irreparable, social morality is subjected to corrosion can hardly be avoided. The low efficiency of government policy means that the policy cannot ensure the best allocation of resources. On the one hand, as an independent rational person, civil servants at all levels are regarded as a special interest group. They have the conditions and motivations to make 
decisions based on the principle of maximizing individual utility rather than maximizing the public and social interests. On the other hand, regulatory capture phenomenon, or maintain the existing unreasonable policy implementation pattern, or the introduction of the new policy is not fair, or hinder the old unreasonable system abolished, or make progress and scientific measures difficult, which will undoubtedly reduce the government's public administrative efficiency, even the gradual erosion of its scientific ability decision making.

\section{Moral Hazard Control Methods of Civil Servants in New Era}

\subsection{Perfect Education Process}

Effective occupation ethics education should not only have internalized the educator and the educated, the educational process is an important link to ensure the effect of education. The rationalization of education content. Targeted for training, to ensure the scientific and effective training content. The diversification of the subject of education. To be bold and innovative, abandoned the former simply relying on Administrative College training at all levels, and actively introduce multiple training subjects. The diversification of education methods. You can take multiple education methods, such as heuristics, dialogue, or case discussion, these civil servants can stimulate interest in learning, and make them have the sense of responsibility in the process of learning. The combination of collective and individual education form. For on the job occupation moral examination of civil servants should be given to special education: when carry out the collective education activities should pay attention to the civil servant individual participation, to receive a good education. As the occupation ethics education of civil servant's occupation ethics needs in-depth study of the organizers should be civil servants of different categories and levels, and then develop practical training plan, different levels and batch education for civil servants. Only their aptitude to obtain good education effect. Although not the most direct organizer of education, but played a crucial role in the process of civil servants' occupation ethics education. Only their first correct training attitude, and consciously improve the quality of their own occupation ethics, to give the education of civil servants in the exemplary role. Moreover, the lead role that cannot be ignored. The main civil servants as the occupation ethics internalization, must play its subjectivity in education and role to obtain the desired effect of education. Actively cultivate the subjectivity of civil servants. Subjectivity is no education is a problem not to be ignored. Civil servants have good occupation loyalty, not only political thought to keep highly consistent with the Party Central Committee, but also to the party and the people's loyalty, excellence in work, with a strong sense of responsibility and mission. Therefore, to further strengthen the civil servants' occupation responsibility and professionalism, which has high enthusiasm for the work, and the work has a strong play. As a civil servant, have good occupation skills is to better serve the people of the important guarantee. In the occupation moral construction of civil servants, improve the overall quality of civil servants is a very important content. So, for the civil service, to improve the ability of learning, through ideological and professional skills theory learning, improve the understanding of civil affairs, to correct work attitude, to better achieve the idea of serving the people.

\subsection{Strengthen Mechanism Construction}

The construction of civil servants' professional ethics based on the system construction can guide and guide the professional ethics and behavior of civil servants from a wider range. Civil servants are selected after rigorous examination, most of them have ideal, ambition, culture, knowledge, ideological awareness is relatively high. Therefore, we should combine with actual situation of various departments at all levels of civil servants work, study and formulate the socialist core values, to standardize the work of civil servants behavior of various rules and regulations, norms and occupation standard, the refinement of the occupation morals request to work process and in all aspects, so that civil servants can clear the party and the state to promote what and against what requirements of their work behavior in pursuit of what, according to what standards etc.. At present, 
China's civil service management practice, often select, light management. In the management system design, generally more general and vague, coupled with the lack of civil servants' professional ethics in the legal aspects. Therefore, at present, we need to strengthen the system construction and behavior standards specific, and to evaluate and manage the professional ethics behavior of civil servants in daily work. The construction of civil servants' professional ethics based on legalization is the basic requirement for the professional ethics of civil servants. The purpose of the legalization of civil servants' professional ethics is to promote and maintain the professional ethics of civil servants through the legal form, and to avoid the doubt and distrust of the public on the fairness of civil servants' public actions, to ensure the National Trust in public affairs. Civil servants' occupation moral construction, has positive and negative effect to strengthen deterrence occupation moral construction of the civil service, quick, time is long, is a relatively successful experience and ways of governance in developed countries and the management of civil servants, is of great significance.

\subsection{Establish Supervision System}

Administrative ethics supervision refers to the supervision and supervision of the administrative behavior of administrative institutions and administrative personnel in accordance with the relevant ethical principles and norms in the administrative activities. Our country is in the process of economic system transition and social transformation, there is a serious phenomenon of moral anomie of administrative personnel, one of the root causes is the lack of effective administrative ethics supervision mechanism. Civil servants' occupation moral construction supervision system construction based on the relevant regulations, is to promote and implement, and for the supervision and management of civil servants' occupation moral behavior process, if there is not moral behavior, can timely remind the public servant himself, even for the public. To play a good role in the construction of civil servants' professional ethics, the key lies in the establishment of the whole supervision system in advance, in and after the event. According to the characteristics of each industry, departments and positions, problems and workflow links, design supervision content and equipped with staff. In addition to improving the current civil servants' personal property and income declaration system, gift acceptance registration system, but also for civil servants' official activities, career relations, work attitude, work style and work efficiency and other issues of supervision. Advance and open procedures and regulations of civil servants occupation moral requirements, in the inspection in accordance with the procedural requirements, in accordance with the standard procedures after inspection; in addition, the supervision to make the service object and managers at all levels from the bottom up, give full play to the responsibility and interests contradiction party supervision; the media supervision of public opinion from outside to inside, full play the supervisory role of the news media and civil society. Once there are problems and being reported, we should carry out outside supervision and discipline supervision and special investigation.

\section{Conclusion}

The civil service ethics aims to use education and training, legal system and supervision system and a series of external forces and measures to promote the formation of civil servants consciously abide by the law, duty consciousness, which reflects the hard work, efforts to serve our country and people's behavior. Everything we do is to let the people live a happier life and make society fairer.

\section{References}

[1] Zhang Man, Xiao Mingzheng. Innovation and Empirical Research of the Construction of Civil Servants’ Professional Ethics [J]. Chinese Public Administration, 2017(2): 42-46.

[2] Xiao Mingzheng, Zhang Man. Three Essential Issues about the Current Construction of Civil Servants' Professional Ethics [J]. Journal of Peking University (Philosophy and Social Sciences), 2017, 54(3): 125-132. 
[3] Jiang Mengjie. Professional Ethics of Civil Servants [J]. Theory Research, 2014(34): 59-61.

[4] Liu Chang, Zhao Jilun. Path Analysis of Civil Servants Internalization of Professional Ethics in China [J]. Academic Exploration, 2015(11): 106-110. 